\title{
PERSPEKTIF IMAM MALIK TENTANG PENGAWASAN HARGA (STUDI TERHADAP HARGA SEMBAKO OLEH DINAS PERINDUSTRIAN DAN PERDAGANGAN KOTA PALANGKA RAYA)
}

\author{
Sadiani dan Siti Maisyaroh \\ IAIN Palangka Raya
}

\begin{abstract}
Abstrak
Penelitian ini tentang perspektif Imam Malik tentang pengawasanharga (studi terhadap harga sembako oleh Dinas Perindustrian dan Perdagangan Kota Palangka Raya. Fokus penelitian ini tentang: fenomena harga sembako di pasar Palangka Raya. Peran Dinas Perindustrian dan Perdagangan dalam melakukan pengawasan harga sembako di pasar Palangka Raya, Perspektif Imam Malik terhadap pengawasan harga sembako yang dilakukan oleh Dinas Perindustrian dan Perdagangan Kota Palangka Raya. Metode yang digunakan dalam penelitian ini adalah penelitian lapangan (field research) dengan pendekatan kualitatif dan pendekatan fiqh. Objek penelitian adalah harga sembako sedangkan subjeknya Dinas Perindustrian dan Perdagangan Kota Palangka Raya. Teknik pengumpulan data terdiri dari observasi, wawancara, dan dokumentasi, dilanjutkan dengan pengabsahan data dan analisis data. Hasil penelitian dan analisis menunjukan bahwa fenomena harga sembako di pasar Palangka Raya, fluktuatif yaitu turun-naik, manakala harga naik disebabkan beberapa faktor; sembako dipasok berasal dari Jawa, gagal panen, biaya sewa lapak mahal, menjelang bulan ramadhan hingga menjelang idul fitri dan hari natal. Peran Dinas Perindustrian dan Perdagangan Kota Palangka Raya dalam melakukan pengawasan harga sembako di pasar Palangka Raya, petugas dari dinas tersebut melaksanakan tugasnya dengan cara memantau ke pasar, melakukan dialog dengan para pedagang sembako, mengadakan operasi pasar dan pasar murah/ pasar penyeimbang dan pembinaan kepada para pedagang. Perspektif Imam Malik terhadap pengawasan harga sembako yang dilakukan oleh Dinas Perindustrian dan Perdagangan Kota Palangka Raya, yaitu terdapat sedikit perbedaan. Menurut Imam Malik pemerintah boleh menentukan harga sedangkan Dinas Perindustrian dan Perdagangan Kota Palangka Raya bukan sebagai penentu harga melainkan hanya mengawasi dan mengadakan pasar penyeimbang untuk menstabilkan harga pasar.
\end{abstract}

Kata Kunci: pengawasan, dinas perindustrian dan perdagangan, imam malik

\section{PENDAHULUAN}

Kondisi harga sembako yang terjadi di beberapa pasar Kota Palangka Raya bahwa kenaikan harga barang dalam kondisi tertentu seperti menjelang bulan puasa hingga hari raya Idul Fitri dan hari Natal atau tahun baru menjadikan harga bahan pokok naik secara drastis bahkan menyebabkan masyarakat ekonomi lemah dan terpaksa harus menerimanya meskipun kondisi ekonomi mereka tidak siap menerima kenyataan harga barang yang melambung pada situasi tersebut.

Di sinilah pihak berkompeten seperti Dinas Perindustrian dan Perdagangan Kota Palangka Raya berperan dalam kewenangan kedinasannya dalam mengawasi dan menjaga stabilitas harga pasar baik dalam menekan para pedagang untuk tidak menaikan harga barang dagangannya. Dinas Perindustrian dan Perdagangan hanya dapat memberlakukan pasar murah sebagai penyeimbang dari harga barang yang dijual mahal oleh para pedagang pasar. Pasar murah 
tersebut sifatnya hanya temporer atau sewaktu-waktu saja, tidak selama bulan puasa yang sebulan penuh berlangsung.

Kondisi inilah yang menyekat kebebasan individu yang tidak harmoni dan dalam waktu itu pula sulit mewujudkan mekanisme pasar yang mengedepankan aspek moralitas dan kerja sama. Artinya, kenaikan harga barang menyebabkan tidak stabil kondisi kesejahteraan masyarakat ekonomi lemah dan membuat masyarakat mengeluh terutama pada bulan puasa Ramadhan sehingga kegiatan transaksi tersebut akan berdampak ketidakadilan masyarakat ekonomi lemah.

Dari gambaran di atas dihubungkan dengan sejarah ekonomi Islam ketika terjadi kenaikan harga terhadap barang-barang komoditi pada masa Rasul SAW, para sahabat datang menghadap Nabi SAW dan memintanya untuk menetapkan harga-harga di pasar, namun permintaan itu ditolak Nabi SAW dengan jawaban bahwa Allah-lah yang maha penetap harga dan pemberi rizki.

Mencermati kondisi pada zamanNabi Muhammad SAW di atas memberikan pemahaman bahwa Nabi SAW menolak menetapkan harga disebabkan karena kondisi barang yang langka serta penyebab lainnya. Jika dihubungkan dengan kondisi wilayah dan jarak tempuh transportasi pengangkutan barang di Kalimantan Tengah, maka situasi yang demikian dapat menjadi alasan sebagai salah satu kenaikan harga barang karena biaya transportasi yang mahal, sehingga pemerintah tidak punya wewenang untuk campur tangan dalam menetapkan harga. Dengan demikian, fluktuatif harga tersebut terbentuk karena situasi dan kondisi secara alami antara lain karena kelangkaan barang, transportasi angkutan yang jauh dan insiden bencana alam yang dapat menghambat kelancaran pengangkutan bahan pokok (sembako). Untuk terwujudnya mekanisme pasar seperti ini, menurut peneliti nilai-nilai moral seperti persaingan yang sehat, kejujuran, transparansi, keadilan harus senantiasa ditegakkan. Meski demikian, di kalangan para ulama terdapat banyak perbedaan pendapat tentang penetapan harga oleh pemerintah dalam perekonomian. Sebagian ulama ada yang setuju terhadap pemerintah tidak boleh ikut campur dalam menetapkan harga dan sebagian ulama ada yang setuju dengan peran pemerintah dalam intervensi penetapan harga, yang menjelaskan perlu adanya intervensi pemerintah adalah Imam Malik dengan alasan karena menganggap raja atau penguasa harus bertanggung jawab terhadap kesejahteraan rakyatnya. ${ }^{1}$ Oleh karena itu, dibolehkan bagi seorang imam untuk mematok harga. Penetapan harga pada masyarakat itu boleh dilakukan jika dikhawatirkan pelaku pasar akan menafsirkan ketaatan kaum muslimin kepada "mekanisme pasar" dengan penafsiran yang negatif atau disalahgunakan. Memang berdasarkan zahir hadis di atas semua ulama tidak membolehkan adanya penetapan harga, namun yang benar penetapan harga itu boleh dikhawatirkannya kemaslahatan masyarakat.2 Sebaimana hal tersebut penulis akan membahas masalah mengenai: Bagaimana fenomena harga sembako di pasar Palangka Raya?Bagaimana peran Dinas Perindustrian dan Perdagangan Kota Palangka Raya dalam melakukan pengawasan harga sembako di pasar Palangka Raya? Bagaimana perspektif Imam Malik terhadap pengawasan harga sembako yang dilakukan oleh Dinas Perindustrian dan Perdagangan Kota Palangka Raya?

\section{METODE}

Lokasi penelitian adalah Dinas Perindustrian dan Perdagangan Jalan Tjilik Riwut Km. 5 Kota Palangka Raya Provinsi Kalimantan Tengah dan para pedagang sembako.Pendekatan penelitian yang digunakan adalah pendekatan kualitatif dan pendekatan fiqh. Subjek dan objek

\footnotetext{
1 Nur Chamid, Jejak Langkah Sejarah Pemikiran Ekonomi Islam, Yogyakarta: Pustaka Pelajar, 2010, H. 152.

2 Syariah_Bangking, Penetapan Harga Dalam Islam,http:/ / axiku-suxes.blogspot.co.id/ 2009/ 06/ penetapan-harga-dalamislam.htmlDiakses Pada Tanggal 22 Maret 2016.
} 
penelitian 2 orang pihak Dinas Perindustrian dan Perdagangan dan 10 pedagang sembako di pasar Palangka Raya.

Teknik pengumpulan data yang digunbakan berupa observasi, wawancara, dan dokumentasi. Observasi yaitu pada Dinas Perindustrian dan Perdagangan Kota Palangka Raya di Jalan Tjilik Riwut Km 5,5 dan 2 tempat pasar, yaitu Pasar Kahayan dan Pasar Besar Palangka Raya. Wawancara yaitu untuk mengetahui bagaimana peran Dinas Perindustrian dan Perdagangan terhadap pengawasan harga sembako, dan bagaimana harga sembako di pasar Palangka Raya. Dokumentasi berupa fotocopy data daftar harga yang di peroleh dari Dinas Perindustrian dan Perdagangan. Pengabsahan data yang diguankan berupa triangulasi sumber, yaitu membandingkan data hasil observasi dari informan (konsumen) dengan apa yang dinyatakan oleh Disperindag dan data hasil wawancara dengan para pedagang. Analisis data adalah data collection, data reduksi, data display, conclusion, drawing/verifying.

Definisi Operasional dituangkan guna menghindari kesalahan dalam menguraikan variabel-variabel yang dianalisis atau untuk membatasi permasalahan dalam penelitian ini, perlu dijelaskan definisi operasional masing-masing variabel, yaitu sebagai berikut.

- Pengawasan, sebagai proses dalam menetapkan ukuran kinerja dan pengambilan tindakan yang dapat mendukung pencapaian hasil yang diharapkan sesuai dengan kinerja. Dengan pengertian ini Schermerhorn menekankan fungsi pengawasan pada penetapan standar kinerja dan tindakan yang harus di lakukan dalam rangka pencapaian kinerja yang telah ditetapkan.

- Dinas perindustrian dan perdagangan, Dinas Perindustrian dan Perdagangan Juga Koperasi yang mengurus perizinan tempat usaha, penambahan tempat usaha. Dinas Perindustrian dan Perdagangan yakni sebagai alat untuk memberikan binaan, pengarahan, pengawasan, dan menciptakan iklim usaha yang sehat.

- Pemikiran Imam Malik, menurut Imam Malik dan Hanafi seorang penguasa melakukan pematokan harga guna mencegah melakukan terjadinya hal yang merugikan masyarakat, seperti para pedagang menaikan harga secara tajam dari harga normal.

- Sembako merupakan singkatan dari sembilan bahan pokok yang terdiri atas berbagai bahanbahan makanan dan minuman.

\section{HASIL DAN PEMBAHASAN}

\section{Fenomena Harga Sembako di Pasar Palangka Raya}

Fenomena harga sembako di pasar Palangka Raya ternyata fluktuatif terkadang harga jual yang ditetapkan oleh pedagang naik karena sembako yang di pasok berasal dari Jawa, ada juga karena gagal panen, biaya sewa lapak yang mahal, karena menjelang awal puasa ramadhan, hari raya idul fitri dan hari natal, jika mereka tidak menaikan harga, maka mengalami kerugian.

\section{Peran Dinas Perindustrian dan Perdagangan Kota Palangka Raya dalam Pengawasan Harga Sembako di Pasar Palangka Raya}

Dinas Perindustrian dan Perdagangan Kota Palangka Raya dalam pengawasan harga sembako di pasar Palangka Raya, dilakukan sekali seminggu dengan cara menanyakan harga sembilan bahan pokok tersebut dan langsung membuat laporan hasil pengawasan dan ditayangkan di TV plasma Pasar Kahayan. Hal tersebut dilakukan agar masyarakat mengetahui yang Disperindag awasi hanya Pasar Kahayan dan Datah Manuah. Menjelang lebaran harga sembako mengalami kenaikan, maka petugas Disperindag akan mengadakan pasar penyeimbang, yang laksanakan 2 bulan sebelum hari-hari besar kegamaan muslim dan kristen. Hal ini dilakukan oleh Dinas Perindustrian dan Perdagangan karena kenaikan harga sembako disebabkan permintaan banyak, sedangkan stok barang sedikit. Selain itu, karena pengaruh cuaca yang 
tidak menentu, sementara pedagang pasar Kota Palangka Raya masih mengandalkan stok bahan pokok dari pulau Jawa. Meski demikian intervensi Dinas Perindustrian dan Perdagangan ketika harga naik dengan melakukan sidak (inspeksi mendadak), pengawasan dan pembinaan kepada para pedagang dengan melakukan wawancara guna mencari solusi tentang penyebab harga sembako naik melambung tinggi di pasar kota Palangka Raya. Jika dalam pengawasan Dinas Perindustrian dan Perdagangan Palangka Raya menemukan adanya pedagang yang menaikan harga untuk mencari keuntungan yang lebih banyak, maka Dinas Perindustrian dan Perdagangan tidak melakukan tindakan untuk menyita barang pedagang tersebut, sebab tugas Dinas Perindustrian dan Perdagangan hanya melakukan pengawasan pembinaan agar harga barang tersebut jangan sampai melonjak. Selain itu, Dinas Perindustrian dan Perdagangan tidak memiliki hak untuk mengambil barang milik pedagang di pasar Palangka Raya.

Menurut pengamatan peneliti di dua pasar yang ada di Palangka Raya, melonjaknya harga bahan sayuran itu masih dalam batas toleransi yakni tidak melebihi 30 persen. Para pedagang senatiasa diingatkan oleh Dinas Perindustrian dan Perdagangan agar tidak mencari keuntungan yang besar dengan memanfaatkan kebutuhan terutama menjelang hari-hari besar. Untuk mengatasi melambungnya harga pihak Dinas Perindustrian dan Perdagangan akan mengadakan operasi pasar dan pasar murah/pasar penyeimbang yang dilakukan untuk mengantisipasi kelangkaan bahan pokok untuk kebutuhan masyarakat.

\section{Perspektif Imam Malik terhadap Pengawasan Harga Sembako yang Dilakukan oleh Dinas Perindustrian dan Perdagangan Kota Palangka Raya}

Mencermati pengawasan yang dilakukan oleh Disperindag terhadap para pedagang di dua pasar yang peneliti lakukan, dihubungkan dengan pemikiran Imam Malik tentang peran penguasa terhadap kesejahteraan rakyat yang melakukan pembelian barang kepada pedagang maka tindakan pengawasan yang dilakukan oleh Disperindag tersebut menurut peneliti sudah mendekati kesesuaian dengan pemikiran Imam Malik. Untuk membuktikan analisis peneliti ini, maka berikut ini diuraikan tentang beberapa pemikiran Imam Malik yang disandarkan pada alQuran, Hadis Nabi SAW, serta beberapa kaidah ushul fiqh dalam mengkaji dan menganalisis terhadap peran pemerintah dalam melakukan pengawasan harga sembako dipasar Palangka Raya.

Pada dasarnya Imam Malik menekankan bahwa penguasa (raja) harus turun tangan dalam mengawasi kesejahteraan masyarakatnya, mengingat bahwa raja atau penguasa harus bertanggung jawab terhadap kesejahteraan rakyatnya. Malik mendorong para penguasa agar bertanggung jawab penuh terhadap kepedulian terhadap pemenuhan kebutuhan rakyatnya.3jika dalam pemerintahan beriktikad baik untuk memberikan kesejahteraan dan ketentraman kepada masyarakatnya, maka pemerintah harus membagi tugas kepada bawahannya untuk memiliki peran guna melaksanakan program dari pemerintah itu. Demikian halnya dalam mengatur peredaran barang yang dibutuhkan oleh masyarakat, maka pemerintah harus mengawasi peredaran barang, penyetokan barang, dan penjualannya harus selalu mendapat pengawasan agar tidak menyulitkan kehidupan masyarakat yang memerlukan sembako tersebut.

Dalam konteks kontemporer termasuk menyikapi fenomena pernigaan dalam suatu wilayah pemerintahan tentunya tidak boleh terlepas dari jiwa seorang pemimpin. Oleh karena itulah setiap kebijakan yang mengandung manfaat dan maslahat bagi rakyat, maka itulah yang direncanakan, dilaksanakan, diorganisasikan, dan dinilai/ dievaluasi kemajuannya. Sebaliknya kebijakan yang mendatangkan mudharat dan mafsadah bagi rakyat, itulah yang harus

${ }^{3}$ Nur Chamid, Jejak Langkah Sejarah Pemikiran Ekonomi Islam, Pustaka Pelajar: Yogyakarta, 2010, H.152. 
disingkirkan dan dijauhi. Terkait dengan pengawasan yang dilakukan oleh Dinas Perindustrian dan Perdagangan Kota Palangka Raya sebagaimana hasil penelitian peneliti yang telah diuraikan di atas, hal tersebut relevan dengan pemikiran Imam Malik yang menganjurkan perlunya pengawasan pemerintah agar sistem perekonomian tidak kacau di masyarakat. Pemikiran Malik ini relevan dengan ilmu ekonomi mengenai maslahah yang berguna untuk individu atau sosial. Selain itu, Imam Malik selalu menggunakan konsep maslahah dengan membahas permasalahan yang tidak ter-cover teks Qur'an dan Sunnah.4

Selanjutnya, ta'sir (penetapan harga) menurut Imam Malik yang juga didukung oleh Imam Hanafi bahwa seorang penguasa melakukan pematokan harga guna mencegah melakukan terjadinya hal yang merugikan masyarakat, seperti para pedagang menaikan harga secara tajam dari harga normal. Dalam kondisi demikian, dibolehkan bagi penguasa untuk melakukan pematokan harga setelah memusyawarhkannya dengan pihak-pihak yang ahli dalam salah satu itu. Pemikiran Malik ini, berbeda dengan apa yang dilakukan oleh Dinas Perindustrian dan Perdagangan Kota Palangka Raya. Mereka tidak menggunakan metode yang digunakan oleh imam Malik, yaitu melakukan pematokan harga barang, tetapi Dinas Perindustrian dan Perdagangan melakukan langkah pasar penyeimbang sebagai salah satu cara mengatasi masalah terkait kenaikan harga pada saat tertentu hari-hari besar keagamaan lainnya, yang diadakan di tiap kelurahan. Sesuai dengan keseimbangan pasar akan tercapai jika jumlah produk yang diminta sama dengan jumlah produk yang ditawarkan atau harga pokok yang ditawarkan sama dengan harga produk yang diminta pembeli. Pada saat itu, akan terjadi transaksi antara penjual dan pembeli, karena telah terjadi kesepakatan mengenai harga dan atau jumlah produk.

Dengan demikian, kemaslahatan orang banyak dapat terjaga dan harga barang yang mahal yang akan merugikan masyarakat dapat dicegah.

Adapun landasan yang dijadikan acuan oleh ulama yang membolehkan hal ini adalah beberapa kaidah dasar fikih: 5

$$
\text { لاضررو لاضرار }
$$

Artinya: Tidak boleh ada bahaya dan tidak boleh membahayakanan dalam kaidah lain disebutkan. Selain kaidah di atas di dukung pula dengan kaidah ushul lainnya, yaitu الضَّرريزل

Artinya: kemudharatan itu harus dilenyapkan

Kaidah selanjutnya,

يتحمَّل الضَّرَر الخاصلمنع الضَّر العام

Artinya: kemudharatan yang khusus dapat ditoleransi guna mencegah timbulnya kemudhratan yang bersifat umum.

Dari kaidah di atas, pencegahan makna darurat di sini menurut pemahaman peneliti tidak saja ditujukan pada masyarakat pembeli melainkan juga, tidak memudaratkan pada para pedagang penjual sembako. Dengan demikian para pedagang tidak boleh dipaksa untuk menjual barangnya, namun hanya dilarang menjualnya di luar harga yang telah dipatok penguasa tersebut. Harga yang dipandang oleh penguasa sama-sama menguntungkan bagi penjual dan pembeli. Jadi, para pedagang tersebut tidak boleh dihalangi untuk mencari keuntungan, sebagaimana tidak dibolehkan bagi mereka melakukan tindakan yang merugikan orang banyak. Hal ini sebagaimana penolakan Rasulullah SAW melakukan pematokan harga bukan karena penolakan

\footnotetext{
${ }^{4}$ Ibid.

${ }^{5}$ Baca Pintar, Qawa'id Fiqh At Tasarraful Imam Alal Ra'yani, https// www.pintarbacacepat.blogspot.com/ 2016/ 01/ qowaid-fiqh-attasarroful-imam-alal.html?m=1 Diakses Pada Tanggal 4 Mei 2017.
} 
terhadap pematokan harga itu sendiri, namun karena alasan yang mewajibkan ditempuhnya tindakan tersebut, yaitu kesewenang-wenangan dari para pedagang dimana para pedagang di saat itu masih menjual barang dagangan mereka dengan harga yang setimpal. Adapun terjadinya kenaikan harga ketika itu bukanlah disebabkan upaya (ulah) para pedagang, namun disebabkan berlakunya hukum pasokan dan permintaan (supply-demand) di pasar, yaitu ketika pasokan barang sedikit, maka harga akan naik. Oleh karena itu, tidak diperlukan pematokan harga jika tidak ada hal yang mendesak untuk itu. Contohnya dalam situasi barang tersedia secara luas di pasar dan dijual dengan harga yang setimpal, tanpa kesewenang-wenangan atau tindakan yang merugikan konsumen.

Selain yang dicontohkan oleh Nabi Muhammad SAW, sebagaimana yang telah diuraikan di atas, Nabi Muhammad juga merupakan seorang pedagang profesional dan selalu menjunjung tinggi kejujuran, ia mendapat julukan "al-amin" ketika remaja. Selanjutnya setelah perpindahan (hijrah) Rasulullah SAW ke Madinah, maka Beliau menjadi pengawas pasar (muhtasib). Pada saat itu, mekanisme pasar sangat dihargai. Hal ini menggambarkan bahwa salah satu bukti adanya Rasulullah SAW menolak untuk membuat kebijakan, pada saat harga sedang naik karena dorongan permintaan penawaran yang alami.

Gambaran lain bahwa Nabi SAW tidak mau menetapkan harga jual dengan alasan bahwa dengan menetapkan harga akan mengakibatkan kezaliman jika kenaikan harga tersebut terjadi secara alami (faktor cuaca, jarak tempuh yang jauh, dan biaya sewa lapak yang mahal). Sedangkan zalim adalah haram. Hal inilah yang terjadi dan yang dilakukan oleh Dinas Perindustrian dan Perdagangan Kota Palangka Raya di pasar, karena jika harga yang ditetapkan terlalu mahal, maka akan menzalimi pembeli, dan jika harga yang ditetapkan terlalu rendah, maka akan menzalimi penjual. Seiring dengan situasi dan kondisi seperti itulah Imam Malik berpendapat bahwa dibolehkan penetapan harga untuk barang-barang hajiyat (sekunder), hal ini dilakukan untuk menghindari hal-hal yang tidak diinginkan. Yaitu, apabila pemilik barang dagangan mematok harga yang tinggi, maka dalam kondisi seperti ini pemimpin dan stafnya berhak menetukan harga dengan tujuan untuk kemaslahatan masyarakat. Jikalau niat penetapan harga untuk kebaikan dan maslahah untuk masyarakat, maka ta'sir tidak apa-apa dilakukan, akan tetapi pemikiran imam Malik di atas seakan di ganti keberlakuannya oleh Dinas Perindustrian dan PerdaganganPalangka Raya dengan cara pasar penyeimbang yang tidak secara langsung menekan dan mengatasi normalisasi harga barang.

Dengan demikian, menurut peneliti Dinas Perindustrian dan Perdagangan Palangka Raya telah melakukan improvisasi pengawasan terhadap pasar agar keadaan pasar terhindar dari perilaku menyimpang para pelaku bisnis di dalam pasar. Terkait dengan pengawasan pasar ini menurut Malik, seorang pengawas pasar mempunyai kewenangan untuk menindak para pelaku kejahatan di dalam. Kejahatan tersebut bisa saja berbentuk beberapa kecurangan yang mengakibatkan kerugian bagi pihak lain. Namun metode imam Malik ini tidak dilakukan oleh Dinas Perindustrian dan Perdagangan Palangka Raya, melainkan diganti dengan cara pendekatan pembinaan kepada para pedagang dengan memberikan wejangan, nasihat, dan arahan agar mereka tidak mengulang hal tersebut.

\section{PENUTUP}

\section{Kesimpulan}

1. Fenomena harga sembako di pasar Palangka Raya ternyata fluktuatif, yaitu terkadang harga jual yang ditetapkan oleh pedagang naik karena sembako yang dipasok berasal dari Jawa, ada juga karena gagal panen, biaya sewa lapak yang mahal, karena menjelang awal puasa 
ramadhan, hari raya idul fitri dan hari natal, jika mereka tidak menaikan harga, maka mengalami kerugian.

2. Peran Dinas Perindustrian dan Perdagangan Kota Palangka Raya dalam melakukan pengawasan harga sembako di pasar Palangka Raya. Mereka laksanakan dengan cara memantau secara langsung ke pasar yang ada di Palangka Raya dan melakukan dialog dengan para pedagang terkait dengan fenomena harga sembako yang pelaksanaannya dilakukan seminggu sekali serta mengadakan operasi pasar dan pasar murah/ pasar penyeimbang sebagai langkah pengawasan terhadap antisipasi melambungnya harga sembako di pasar Palangka Raya, di samping itu Dinas Perindustrian dan Perdagangan juga pembinaan kepada para pedagang.

3. Perspektif Imam Malik terhadap pengawasan harga sembako yang dilakukan oleh dinas perindustrian dan perdagangan kota Palangka Raya hanya masuk dalam kategori pengawasan saja dan bukan sebagai penentu kebijakan terhadap fluktuatif harga sembako yang ada di pasar Palangka Raya.

\section{Saran}

1. Para pedagang diharapkan bersikap jujur dan adil, jangan semena-mena menaikan harga jika tidak dalam kondisi jarak tempuh yang dekat serta distribusi barang yang stabil.

2. Bagi Dinas Perindustrian dan Perdagangan diharapkan untuk selalu memantau perkembangan harga barang dan stabilitas harga barang tersebut dilihat dari situasi dan kondisi keberadaan barang itu sendiri dan juga jarak tempuh transportasi pengangkutannya.

\section{DAFTAR PUSTAKA}

Baca Pintar, Qawa'id Fiqh At Tasarraful Imam Alal Ra'yani, https//www.pintarbacacepat.blogspot.com/2016/01/ qowaid-fiqh-at-tasarroful-imam-alal.html?m=1 Diakses Pada Tanggal 4 Mei 2017.

Chamid, Nur. 2010. Jejak Langkah Sejarah Pemikiran Ekonomi Islam. Yogyakarta: Pustaka Pelajar.

Syariah_Bangking, Penetapan Harga Dalam Islam. http:// axiku-suxes.blogspot.co.id/ 2009/ 06/ penetapan-harga-dalam-islam.html Diakses Pada Tanggal 22 Maret 2016. 